\title{
Biological sample collections from minors for genetic research: a systematic review of guidelines and position papers
}

\author{
Kristien Hens ${ }^{*, 1}$, Herman Nys ${ }^{1}$, Jean-Jacques Cassiman ${ }^{1}$ and Kris Dierickx ${ }^{1}$ \\ ${ }^{1}$ Centre for Biomedical Ethics and Law, Kapucijnenvoer 35/3 Box 7001, Leuven, Belgium
}

Stored tissue samples are an important resource for epidemiological genetic research. Genetic research on biological material from minors can yield valuable information on the development and genesis of earlyonset genetic disorders and the early interaction of environmental and genetic factors. The use of such tissue raises some specific ethical and governance questions, which are not completely covered by the discussion on biological materials from adults. We have retrieved 29 guidelines and position papers pertaining to the storage and use of biological tissue samples for genetic research, originating from 27 different organizations. Five documents have an international scope, three have an European scope and 21 have a national scope. We discovered that 11 of these documents did not contain a section on biological materials from minors. The content of the remaining 18 documents was categorized according to four themes: consent, principles of non-therapeutic research on vulnerable populations, ethics committee approval and difference between anonymous and identifiable samples. We found out that these themes are not consistently mentioned by each document, but that documents discussing the same themes were mostly in agreement with their recommendations. However, a systematic reflection on the ethical and policy issues arising from the participation of minors in biobank research is missing.

European Journal of Human Genetics (2009) 17, 979-990; doi:10.1038/ejhg.2009.9; published online 18 February 2009

Stored tissue sample collections for genetic research exist in different forms. Some of these collections provide a resource for potentially unlimited genetic research, and gather samples and data from specific populations. An example is the 'UK biobank'. ${ }^{1}$ Other collections are stored for research on a specific disease. Collections that were originally gathered for different purposes, for example blood spot cards for newborn screening, could be reused for genetic research. ${ }^{2}$

Genetic research on biological material from minors and the associated medical records can yield valuable information on the development and genesis of early-onset genetic disorders and the early interaction of environmental and

*Correspondence: K Hens, Centre for Biomedical Ethics and Law, Kapucijnenvoer 35/3 Box 7001, Leuven 3000, Belgium.

E-mail: Kristien.Hens@med.kuleuven.be

Published online 18 February 2009 genetic factors. For example, Rasmussen ${ }^{3}$ describes the incorporation of DNA sample collections into the 'National Birth Defects Prevention Study' in the United States to identify the risk factors for birth defects. Studies such as the 'Avon Longitudinal Study of Parents and Children' in Bristol (children of the nineties) use genetic, phenotypic and environmental information of 14000 babies from their conception onwards to study the interaction between these data. ${ }^{4}$

An extensive ethical literature exists on the collection, storage and use of biological samples for genetic research. The overwhelming majority of these documents discuss issues of privacy, confidentiality, commercialization and consent. ${ }^{5-14}$ However, research on pediatric data raises specific ethical questions with regard to consent and privacy. For example, who should give consent to the inclusion of tissue and data from children? Is the general requirement that non-therapeutic 
research can only be done with children if it involves no more than minimal risk, applicable to biobank research? We shall review whether and how guidelines and policy documents discuss children in the context of storing biological samples and DNA for non-therapeutic research.

\section{Methods}

MedLine, Embase and Google Scholar were used as a primary source of information to identify relevant literature. Official websites of ethical committees, professional organizations and regulating bodies from the US and the European Union were equally searched. ${ }^{15,16}$ More information was gathered on the basis of the bibliographical data in these documents. We focused on documents about genetic databases (so-called biobanks) and about stored biological samples that mentioned genetic research. Documents discussing archived human tissue without mentioning genetic research were discarded. General documents on genetic research were preserved, as long as they at least mention banking of data. Only documents in French, German, English or Dutch were preserved, that were no older than 1990. As the focus was on guidelines and recommendations, legally binding documents were not included.

Some confusion may exist regarding the term 'children'. We have included documents that mention 'children' or 'minors' and have covered the lifespan from birth till the legal age of maturity. In the text, 'children' and 'minors' will be used synonymously.

\section{Results \\ Guidelines and position papers}

We have retrieved 29 different guidelines and position papers (Table 1, numbered references to this table) pertaining to the storage and use of biological tissue samples for genetic research. The documents covered the period 1994-2007, with a peak in number of guidelines in 2002 (7 out of 29 guidelines). The guidelines originated from 27 different organizations. Guidelines were issued by national bioethics committees (13), medical associations (6), genetic associations (5), other bioethical associations (1), UNESCO (1) and the Council of Europe (1). Five documents had an international scope, three had an European scope and 21 had a national scope: United States of America (4), United Kingdom (3), Germany (2), Australia (1), Iceland (1), The Netherlands (1), Finland (1), Israel (1), Singapore (1), Canada (1), France (1), Ireland (1), Greece (1) and Austria (1).

One international guideline (11) dealt with biomedical research in general, but as it contained a section on stored tissue samples, we included it as well. One document (4) dealt with clinical investigation, but was included because the document from the same organization (AMA) that deals with DNA databanks (16) explicitly refers to this document for vulnerable persons.

At the moment of writing of this paper, the OECD (Organization of Economic Co-operation and Development) is working on a document provisionally titled 'Guidelines for Human Biobanks and Genetic Research Databases'. As this is still open for comments, we have decided not to include the draft version of the document in our discussion.

We first acknowledged whether the guidelines mentioned the use of tissue samples from minors. It turned out that 11 out of 29 documents did not mention such use. We then categorized the remaining 18 documents according to the themes they discussed with regard to this topic. We distilled four major themes: consent, principles of nontherapeutic research on vulnerable populations, ethics committee approval and difference between anonymous and identifiable samples (Table 2).

\section{Consent}

A major theme discussed is the issue of consent. First of all the guidelines discuss who should give consent to the donation, storage and use of the tissue samples from children. Some guidelines also discuss the issue of a child's assent (permission) or dissent (refusal). A third question is whether and when a minor should be recontacted to give full consent.

17 out of 18 documents state that a legal guardian should give consent. In this regard, a legal representative, guardian or legal proxy is named $(1,4,6,11,14,17,19,20$, $22,23,26,27,28,29)$, a parent $(11,23,27,28,29)$, someone with parental responsibility $(2,9)$, a relative $(18,28)$ and someone designated to protect the interests of the subject (18). Four mention parents $(9,22,27,6)$. Only one guideline mentions that it must be both parents (6): 'In general consent should be obtained from both parents'.

Only four documents give further specification on the representative who gives consent. CIOMS (11) mentions that the parent or guardian who gives permission for a child to participate in research should be given the opportunity, to a reasonable extent, to observe the research as it proceeds, so as to be able to withdraw the child if the parent or guardian decides it is in the child's best interest to do so. The Bioethics Advisory Committee, Singapore (14) mentions that the extent and scope of a given legal proxy's lawful authority to give consent may well depend on the particular circumstances and on the putative proxy's legal relationship with the donor. The French Comité Consultatif National (18) stresses that although there is possibly no other solution than to gather consent from some trusthworthy person, one cannot 'ignore that a collection based on samples from children necessarily carries knowledge about a whole lifetime'. Hence, they question the 
Table 1 Overview of sources used

\begin{tabular}{|c|c|c|c|c|c|}
\hline Number & Year & Scope & Guideline developer & Guideline title & Composition of the group that authored the guideline \\
\hline 1 & 1994 & The Netherlands & $\begin{array}{l}\text { Gezondheidsraad: } \\
\text { Commissie } \\
\text { Lichaamsmateriaal } \\
\text { voor bijzondere } \\
\text { doeleinden. }{ }^{77}\end{array}$ & $\begin{array}{l}\text { Naar goed gebruik. } \\
\text { Lichaamsmateriaal in } \\
\text { de gezondheidszorg }\end{array}$ & $\begin{array}{l}\text { The 'Commissie lichaamsmateriaal voor bijzondere } \\
\text { doeleinden' is composed of P Hoedemaeker, } \\
\text { I de Beaufort, D Bootsma, P Breslau, H Bruinse, } \\
\text { J Gevers, A Gittenberg-de Groot, K Hamenlynck, } \\
\text { K Jager, N Mul, H Roscam, A Schreurs, P Strengers, } \\
\text { E van Veen, I Visser and E Olsthoorn-Heim. They } \\
\text { consulted two experts, P Brombacher and } \\
\text { J Vandenbrouck }\end{array}$ \\
\hline 2 & 1995 & United Kingdom & $\begin{array}{l}\text { Nuffield Council on } \\
\text { Bioethics }\end{array}$ & $\begin{array}{l}\text { Human tissue, ethical } \\
\text { and legal issues }\end{array}$ & $\begin{array}{l}\text { The working group on human tissue was } \\
\text { composed of R Hurley, K Baker, C Berry, } \\
\text { G Dworkin, TM Jones, I Kennedy, K Mooney } \\
\text { and O O'Neill. }\end{array}$ \\
\hline 3 & 1998 & International & $\begin{array}{l}\text { Human Genome } \\
\text { Organization } \\
(\mathrm{HUCO})^{19}\end{array}$ & $\begin{array}{l}\text { Statement on DNA } \\
\text { sampling: Control and } \\
\text { access }\end{array}$ & $\begin{array}{l}\text { HUGO Ethics Committee. Its current members } \\
\text { are R Chadwick, K Berg, A Daar, K Kato, D Macer, } \\
\text { T Murray, I Verma and || Mulvihill }\end{array}$ \\
\hline 4 & 1998 & $\begin{array}{l}\text { United States of } \\
\text { America }\end{array}$ & $\begin{array}{l}\text { American Medical } \\
\text { Association }^{20}\end{array}$ & $\begin{array}{l}\text { E-2.07 Clinical } \\
\text { Investigation }\end{array}$ & - \\
\hline 5 & 1999 & $\begin{array}{l}\text { United States of } \\
\text { America }\end{array}$ & $\begin{array}{l}\text { National Bioethics } \\
\text { Advisory Committee }\end{array}$ & $\begin{array}{l}\text { Research involving } \\
\text { human biological } \\
\text { materials: ethical issues } \\
\text { and policy guidelines }\end{array}$ & $\begin{array}{l}\text { The advisory commission is composed of HT } \\
\text { Shapiro, P Backlar, A Brito, AM Capron, EJ Cassell, } \\
\text { RA Charo, JF Childress, DR Cox, RG Dumas, } \\
\text { LM Flynn, CW Greider, SH Holtzman, BO Kramer, } \\
\text { B Lo, L.H. Müke, TH Murray and D Scott-Thomas }\end{array}$ \\
\hline 6 & 2000 & Australia & $\begin{array}{l}\text { National Health and } \\
\text { Medical Research } \\
\text { Council }^{22}\end{array}$ & $\begin{array}{l}\text { Guidelines for genetic } \\
\text { registers and } \\
\text { associated genetic } \\
\text { material }\end{array}$ & $\begin{array}{l}\text { NHMRC documents are prepared by panels of } \\
\text { experts drawn from appropriate Australian } \\
\text { academic, professional, community and } \\
\text { government organizations. }\end{array}$ \\
\hline 7 & 2000 & Iceland & Visindasidanefnd ${ }^{23}$ & Biological Samples & - \\
\hline 8 & 2001 & Europe & $\begin{array}{l}\text { European Society of } \\
\text { Human Genetics } \\
(\text { (ESHG) })^{23,24}\end{array}$ & $\begin{array}{l}\text { DNA storage and DNA } \\
\text { banking for biomedical } \\
\text { research: technical, } \\
\text { social and ethical issues }\end{array}$ & $\begin{array}{l}\text { Public and Professional Policy Committee of the } \\
\text { ESHC (PPPC). Members of the PPPC were S Aymé, } \\
\text { M Bobrow, I Cassiman, G Evers-Kiebooms, } \\
\text { P Farndon, H Kääriäinen, U Kristoffersson, } \\
\text { M Pembrey, S Raeburn, Jörg Schmidtke, } \\
\text { L ten Kate and L Tranebjaerg. }\end{array}$ \\
\hline 9 & 2001 & United Kingdom & $\begin{array}{l}\text { Medical Research } \\
\text { Council }^{25}\end{array}$ & $\begin{array}{l}\text { Human tissue and } \\
\text { biological samples for } \\
\text { use in research - } \\
\text { operational and ethical } \\
\text { guidelines }\end{array}$ & $\begin{array}{l}\text { The working group was composed of } \\
\text { E Johnstone, L Doyal, A Grubb, S Povey, } \\
\text { P Quirke, S Sadeque, A Silman and } \\
\text { G Stamp. }\end{array}$ \\
\hline 10 & 2002 & Finland & $\begin{array}{l}\text { The Sub-Committee } \\
\text { on Medical Research } \\
\text { Ethics (TUKIJA) of the } \\
\text { National Advisory } \\
\text { Board on Health Care } \\
\text { Ethics's }\end{array}$ & $\begin{array}{l}\text { DNA samples in } \\
\text { epidemiological } \\
\text { research }\end{array}$ & $\begin{array}{l}\text { Working group on DNA and Epidemiology was } \\
\text { composed of A Aromaa, V Launis and S Lötjönen. }\end{array}$ \\
\hline 11 & 2002 & International & $\begin{array}{l}\text { Council for } \\
\text { International } \\
\text { Organizations of } \\
\text { Medical Sciences } \\
(\text { CIOMS) }\end{array}$ & $\begin{array}{l}\text { International ethical } \\
\text { guidelines for } \\
\text { biomedical research } \\
\text { involving human } \\
\text { subjects }\end{array}$ & $\begin{array}{l}\text { The group responsible of drafting the various } \\
\text { drafts was composed of FL Stepke, I Bryant, } \\
\text { L de Castro, R Levine, R Macklin, G Tangwa, } \\
\text { F Luna and R Saracci }\end{array}$ \\
\hline 12 & 2002 & International & $\begin{array}{l}\text { Human Genome } \\
\text { Organization } \\
\text { (HUGO) }^{28}\end{array}$ & $\begin{array}{l}\text { Statement on human } \\
\text { genomic databases }\end{array}$ & $\begin{array}{l}\text { HUGO Ethics Committee } 2002 . \\
\text { BM Knoppers, R Chadwick, I Verma, } \\
\text { K Berg, IM Cantu, A Daar, E Engels, } \\
\text { K Kato, M Kirby, D Macer, T Murray, } \\
\text { RZ Qiu, DC Wertz, J Bovenberg and } \\
\text { R Cotton }\end{array}$ \\
\hline
\end{tabular}

Methods used

The recommendations are based on a literature review, a questionnaire sent out to specialists and expert consensus.

The recommendations are the expert consensus.

The recommendations are the expert consensus.

The group has consulted scientists, research administrators and the public. The recommendation are the expert consensus.

The recommendations are the expert consensus.

The recommendations are the expert consensus.

Working drafts of the guidelines were sent out for consultation to a wide range of organizations and human material in research. Their comments were taken into account in developing an interim version which was then published, together with a more detailed report of the working group's discussions, for wider public consultation and input. Comments were received from Research Ethics Committees, from researchers, patient and consumer groups, and from the MRC's Consumer Liaison Group. The recommendations are the expert consensus. The recommendations are the expert consensus.

The group held a set of workshops and meetings. The report was written based on information and comments from different experts and institutions.

The recommendations are the expert consensus. 
Table 1 (Continued)

\begin{tabular}{|c|c|c|c|c|c|c|}
\hline Number & Year & Scope & Guideline developer & Guideline title & Composition of the group that authored the guideline & Methods used \\
\hline 13 & 2002 & Israel & $\begin{array}{l}\text { Bioethics Advisory } \\
\text { Committee of the Israel } \\
\text { Academy of Sciences } \\
\text { and Humanities }\end{array}$ & $\begin{array}{l}\text { Population-based } \\
\text { large-scale collections } \\
\text { of DNA samples and } \\
\text { databases of genetic } \\
\text { information }\end{array}$ & $\begin{array}{l}\text { The Bioethics Advisory Committee is composed } \\
\text { of R Arnon, G Ben-Or, S Berman, M Halperin, } \\
\text { D Heyd, A Kasher, A Keynan, R Ishay, } \\
\text { E Levy-Lahad, M Revel, A Shapira, H Soreq } \\
\text { and Y Segal }\end{array}$ & The recommendations are the expert consensus. \\
\hline 14 & 2002 & Singapore & $\begin{array}{l}\text { Bioethics Advisory } \\
\text { Committee, } \\
\text { Singapore }^{30}\end{array}$ & Human tissue research & $\begin{array}{l}\text { The Bioethics Advisory Committee is composed } \\
\text { of L Pin, D Chan Kum Wah, C Wah Teck, C Yip } \\
\text { Seng, J Elliott, T Kaan, L Lim, L Soo Hoon, } \\
\text { R Magnus, O Yong Yau, T Chorh Chuan } \\
\text { and Z Abidin Rasheed. }\end{array}$ & $\begin{array}{l}\text { The recommendations are the result of a review } \\
\text { of existing publications and a public consultation } \\
\text { process and are the expert consensus. }\end{array}$ \\
\hline 15 & 2002 & United Kingdom & $\begin{array}{l}\text { Human Genetics } \\
\text { Commission }^{31}\end{array}$ & Inside information & $\begin{array}{l}\text { The Human Genetics Commission is composed } \\
\text { of J Sulston, B Almond, S Bain, C Brazell, S } \\
\text { Cunningham-Burley, P Debenham, F Flinter, } \\
\text { R Gardner, J Harris, M Harrison, C Higgins, A Kent, } \\
\text { R Leonard, A Maynard, L Oni, C Patch and } \\
\text { P Sayers. }\end{array}$ & $\begin{array}{l}\text { The group has consulted key national and } \\
\text { international organizations to discuss relevant are } \\
\text { of concern and drew on the work of the Science } \\
\text { Technology Committees of the House of Commo } \\
\text { and the House of Lords. The recommendations are } \\
\text { expert consensus. }\end{array}$ \\
\hline 16 & 2002 & $\begin{array}{l}\text { United States of } \\
\text { America }\end{array}$ & $\begin{array}{l}\text { American Medical } \\
\text { Association }^{32}\end{array}$ & $\begin{array}{l}\text { E-2.079 Safeguards in } \\
\text { the use of DNA } \\
\text { databanks in genomic } \\
\text { research }\end{array}$ & & \\
\hline 17 & 2003 & Canada & $\begin{array}{l}\text { Commission de } \\
\text { l'éthique de la science } \\
\text { et de la technology }\end{array}$ & $\begin{array}{l}\text { Les enjeux éthiques des } \\
\text { banques d'information } \\
\text { génétique: pour un } \\
\text { encadrement } \\
\text { démocratique et } \\
\text { responsable }\end{array}$ & $\begin{array}{l}\text { The working group was composed of } \\
\text { J Patenaude, L Barbeau, A Beauchamp, } \\
\text { D Boucher, I de Champlain, E Deleury, } \\
\text { P Deschaies, J Guédon, M Jean, } \\
\text { M Prémont, G Tincotte and D Duquet }\end{array}$ & The recommendations are the expert consensus. \\
\hline 18 & 2003 & France & $\begin{array}{l}\text { Comité consultatif } \\
\text { national d'éthique } \\
\text { pour les sciences de la } \\
\text { vie et de la santé }\end{array}$ & $\begin{array}{l}\text { Avis } \mathrm{n} 77 \text {, Problèmes } \\
\text { éthiques poses par les } \\
\text { collections de materiel } \\
\text { biologiqueet les } \\
\text { données d'information } \\
\text { associées: 'biobanques' } \\
\text { 'biotheques' }\end{array}$ & $\begin{array}{l}\text { The working group was composed of } \\
\text { N Baumann, A Cambin-Thomsen, } \\
\text { M Canto-Sperber, H Gaumont-Prat, } \\
\text { B Kriegel, M Loizeau, N Questiaux, } \\
\text { S Beloucif, G Bréart and G Orth }\end{array}$ & The recommendations are the expert consensus. \\
\hline 19 & 2003 & International & $\begin{array}{l}\text { United Nations } \\
\text { Educational, Scientific } \\
\text { and Cultural } \\
\text { Organization } \\
\text { (UNESCO) }^{35}\end{array}$ & $\begin{array}{l}\text { International } \\
\text { declaration on human } \\
\text { genetic data }\end{array}$ & $\begin{array}{l}\text { The group responsible for drafting the declaration } \\
\text { was composed of RL Andorno, L DeCastro, } \\
\text { H Galjaard, M Hamdan, R Ida, DA Iljalye, } \\
\text { G Kosztolányi, GB Kutukoljian, PP Majumder, } \\
\text { A McCall Smith, N Questiaux, M Revel, S Rumball, } \\
\text { J Sandor and P Robinson }\end{array}$ & $\begin{array}{l}\text { The group drafted the first draft, which was then } \\
\text { revised by international organizations, specialists } \\
\text { and special-interest groups }\end{array}$ \\
\hline 20 & 2003 & International & $\begin{array}{l}\text { World Health } \\
\text { Organization }(\mathrm{WHO})^{36}\end{array}$ & $\begin{array}{l}\text { Genetic databases. } \\
\text { Assessing the benefits } \\
\text { and the impact on } \\
\text { human and patient } \\
\text { rights }\end{array}$ & $\begin{array}{l}\text { The report has been prepared under the auspices } \\
\text { of the WHO's European Partnership on Patients' } \\
\text { Rights and Citizens' Empowerment. The group } \\
\text { preparing the report consisted of F Dekkers, } \\
\text { A Kent, G Laurie and C Shalev }\end{array}$ & The recommendations are the expert consensus. \\
\hline 21 & 2004 & Germany & $\begin{array}{l}\text { Deutsche Gesellschaft } \\
\text { für Humangenetik }{ }^{37}\end{array}$ & $\begin{array}{l}\text { DNA-banking and } \\
\text { personenbezogene } \\
\text { Daten in der } \\
\text { biomedizinischen } \\
\text { Forschung: } \\
\text { Technische, soziale } \\
\text { und ethische Frage }\end{array}$ & $\begin{array}{l}\text { G Wolff, W Henn, I Schmidtke, W Vogel, K Zerres, } \\
\text { I Nippert, P Propping and CR Bartram }\end{array}$ & The recommendations are the expert consensus. \\
\hline 22 & 2004 & Germany & Nationaler Ethikrat ${ }^{38}$ & Biobanks for research & $\begin{array}{l}\text { The committee is composed of S Simitis, R KOllek, } \\
\text { E Nagel, H Barth, W van den Daele, H Dreier, } \\
\text { E Engels, G Fürst, D Ganten, V Gerhardt, } \\
\text { C Lohkamp, M J Lohse, T Neuer-Miebach, } \\
\text { C Nüsslein-Volhard, P Propping, H Putzhammer, } \\
\text { P Radtke, J Reich, E Schockenhoff, } \\
\text { B Schöne-Seifert, R Schröder, J Taupitz, H Vogel, } \\
\text { K Weber-Hassemer and C Woopen }\end{array}$ & The recommendations are the expert consensus. \\
\hline
\end{tabular}


Table 1 (Continued)

\begin{tabular}{|c|c|c|c|c|c|c|}
\hline Number & Year & Scope & Guideline developer & Guideline title & Composition of the group that authored the guideline & Methods used \\
\hline 23 & 2005 & Ireland & $\begin{array}{l}\text { Irish Council for } \\
\text { Bioethics }^{39}\end{array}$ & $\begin{array}{l}\text { Human Biological } \\
\text { Material: } \\
\text { recommendations for } \\
\text { collection, use and } \\
\text { storage in research }\end{array}$ & $\begin{array}{l}\text { The Irish Council for Bioethics is composed of } \\
\text { D Gleeson, P Whittaker, } \\
\text { P Cunningham, M Dempsey, D Dooley, } \\
\text { M Fitzgerald, P Flanagan, P Hannon, } \\
\text { K Kearon, C Kelleher, M Lawler, T McGleenan, } \\
\text { P MCKenna, M Mulvihill, N O'Brien, F O'Gara, } \\
\text { R O'Regan, A Scott, AA Sheikh and S Strain. }\end{array}$ & $\begin{array}{l}\text { The recommendations are the result of evaluation of } \\
\text { international best practice and wide-ranging } \\
\text { discussions by the working group and are the expert } \\
\text { consensus. }\end{array}$ \\
\hline 24 & 2006 & Europe & Council of Europe $\mathrm{e}^{40}$ & $\begin{array}{l}\text { Recommendation REC } \\
\text { (2006) four of the } \\
\text { Committee of } \\
\text { Ministers to member } \\
\text { states on biological } \\
\text { materials of human } \\
\text { origin }\end{array}$ & - & - \\
\hline 25 & 2006 & Greece & $\begin{array}{l}\text { National Bioethics } \\
\text { Commission }\end{array}$ & $\begin{array}{l}\text { Recommendation on } \\
\text { banks of biological } \\
\text { material of human } \\
\text { origin (biobanks) in } \\
\text { biomedical research }\end{array}$ & $\begin{array}{l}\text { The National Bioethics Commission is composed } \\
\text { of G Maniatis, S Agouridis, M Dragona-Monachou, } \\
\text { CB Krimbas, D Roupakias, P Sourlas, C Tsoukalas } \\
\text { and J Vlahoyiannis }\end{array}$ & The recommendations are the expert consensus. \\
\hline 26 & 2006 & Switzerland & $\begin{array}{l}\text { Swiss Academy of } \\
\text { Medical Sciences }{ }^{41}\end{array}$ & $\begin{array}{l}\text { Biobanks: obtainment, } \\
\text { preservation and } \\
\text { utilization of human } \\
\text { biological material. } \\
\text { Medical-ethical } \\
\text { guidelines and } \\
\text { recommendations }\end{array}$ & $\begin{array}{l}\text { The subcommittee appointed to draw up } \\
\text { guidelines was composed of V Dittmann, } \\
\text { M Bargetzi, A Bondolfi, B Elger, } \\
\text { M Gersbach-Forrer, H Kurz, W Pletscher, } \\
\text { M Salathé, H Schneider, D Sprumont, } \\
\text { E Stauffer and M Vallotton. Experts consulted are } \\
\text { R Bühlmann, L Bühler, W Holzgreve and } \\
\text { V Schwander }\end{array}$ & The recommendations are the expert consensus. \\
\hline 27 & 2007 & Austria & $\begin{array}{l}\text { Austrian Bioethics } \\
\text { Commission }^{42}\end{array}$ & $\begin{array}{l}\text { Biobanken für die } \\
\text { medizinische } \\
\text { Forschung }\end{array}$ & - & Th \\
\hline 28 & 2007 & European & $\begin{array}{l}\text { The European } \\
\text { Nutrigenomics } \\
\text { Organisation } \\
\text { (NuGO) }^{43}\end{array}$ & $\begin{array}{l}\text { Bioethics guidelines on } \\
\text { human studies }\end{array}$ & $\begin{array}{l}\text { The NuGO Bioethics Working Group is composed } \\
\text { of MM Bergmann, M Bodzioch, L Bonet, C Defoort } \\
\text { and G Lietz. Experts involved in the generation of } \\
\text { the NuGO Guidelines are D Castle, A Cutter, } \\
\text { E Engels, G Javashvili, H Roscam Abbing and } \\
\text { U Görman }\end{array}$ & The recommendations are the expert consensus. \\
\hline 29 & 2007 & $\begin{array}{l}\text { United States of } \\
\text { America }\end{array}$ & $\begin{array}{l}\text { National Cancer } \\
\text { Institute }\end{array}$ & $\begin{array}{l}\text { Best practices of } \\
\text { biospecimen resources }\end{array}$ & $\begin{array}{l}\text { The Biorepository Coordinating Committee (BCC) } \\
\text { is composed of AD Barker, LM Bennett, CD Berg, } \\
\text { CC Compton, H Erickson, I Fore, DS Gerhard, } \\
\text { J Gillespie, MK Henderson, A Hruszkewycz, } \\
\text { JM Jessup, P Kim, SM Lemrow, J Levine, } \\
\text { NC Lockhart, IA Lubensky, HM Moore, K Pitt, } \\
\text { JA Schneider, D Seminara, SE Taube, JW Thomas, A } \\
\text { Umar, J Vaught, L Weiss and R Yassin. The Office of } \\
\text { Biorepositories and Biospecimen Research is } \\
\text { composed of C Compton, N Lockhart, H Moore } \\
\text { and J Vaught. }\end{array}$ & $\begin{array}{l}\text { The guidelines were laid down by surveys and } \\
\text { community forums, and two workshops were } \\
\text { attended by ethical, legal and policy experts and } \\
\text { cancer research experts. The recommendations are } \\
\text { the expert consensus. }\end{array}$ \\
\hline
\end{tabular}




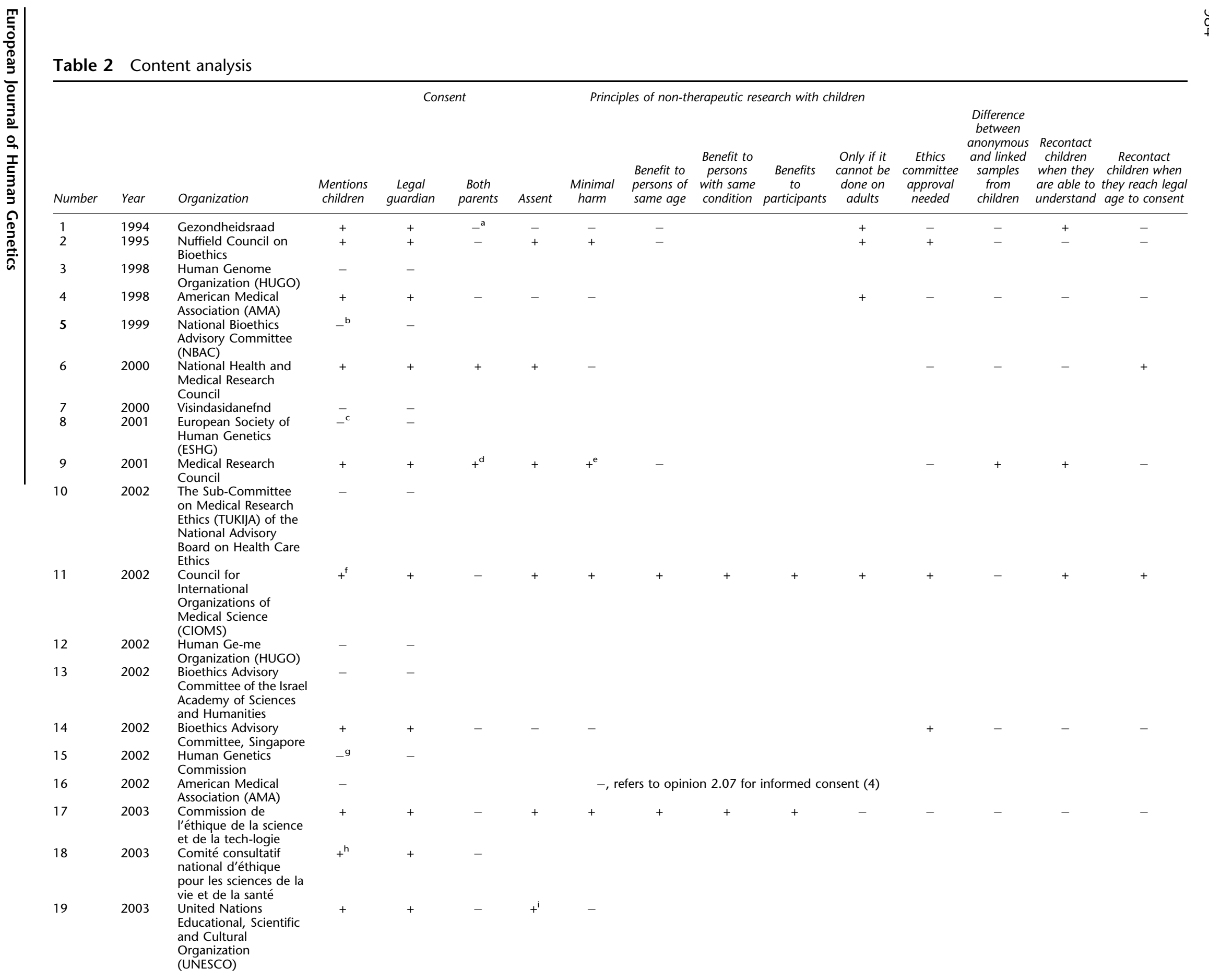




\begin{tabular}{|c|c|c|c|c|c|c|c|c|c|c|c|c|c|c|c|}
\hline Number & Year & Organization & $\begin{array}{l}\text { Mentions } \\
\text { children }\end{array}$ & $\begin{array}{l}\text { Legal } \\
\text { guardian }\end{array}$ & $\begin{array}{l}\text { Both } \\
\text { parents }\end{array}$ & Assent & $\begin{array}{l}\text { Minimal } \\
\text { harm }\end{array}$ & $\begin{array}{l}\text { Benefit to } \\
\text { persons of } \\
\text { same age }\end{array}$ & $\begin{array}{l}\text { Benefit to } \\
\text { persons } \\
\text { with same } \\
\text { condition }\end{array}$ & $\begin{array}{c}\text { Benefits } \\
\text { to } \\
\text { participants }\end{array}$ & $\begin{array}{l}\text { Only if it } \\
\text { cannot be } \\
\text { done on } \\
\text { adults }\end{array}$ & $\begin{array}{c}\text { Ethics } \\
\text { committee } \\
\text { approval } \\
\text { needed }\end{array}$ & $\begin{array}{l}\text { Difference } \\
\text { between } \\
\text { anonymous } \\
\text { and linked } \\
\text { samples } \\
\text { from } \\
\text { children }\end{array}$ & $\begin{array}{l}\text { Recontact } \\
\text { children } \\
\text { when they } \\
\text { are able to } \\
\text { understand }\end{array}$ & $\begin{array}{l}\text { Recontact } \\
\text { children when } \\
\text { they reach legal } \\
\text { age to consent }\end{array}$ \\
\hline 20 & 2003 & $\begin{array}{l}\text { World Health } \\
\text { Organization (WHO) }\end{array}$ & + & + & - & + & + & + & + & + & - & + & $+^{j}$ & - & - \\
\hline 21 & 2004 & $\begin{array}{l}\text { Deutsche Gesellschaft } \\
\text { für Humangenetik }\end{array}$ & + & - & & - & + & - & & & & + & - & & \\
\hline 22 & 2004 & Nationaler Ethikrat & + & + & $t^{\mathrm{k}}$ & + & + & + & + & + & + & - & - & - & - \\
\hline 23 & 2005 & $\begin{array}{l}\text { Irish Council for } \\
\text { Bioethics }\end{array}$ & + & + & - & + & + & + & + & - & + & - & - & + & - \\
\hline $\begin{array}{l}24 \\
25\end{array}$ & $\begin{array}{l}2006 \\
2006\end{array}$ & $\begin{array}{l}\text { Council of Europe } \\
\text { National Bioethics } \\
\text { Commission }\end{array}$ & $\begin{array}{l}-1 \\
-\end{array}$ & - & & & & & & & & & & $t^{m}$ & - \\
\hline 26 & 2006 & $\begin{array}{l}\text { Swiss Academy of } \\
\text { Medical Sciences }\end{array}$ & + & + & - & - & - & & & & & - & - & + & - \\
\hline 27 & 2007 & $\begin{array}{l}\text { Austrian Bioethics } \\
\text { Commission }\end{array}$ & + & + & $t^{\mathrm{n}}$ & + & + & - & & & & + & - & & \\
\hline 28 & 2007 & $\begin{array}{l}\text { European Nutroge- } \\
\text { mics Organization } \\
\text { (NuGO) }\end{array}$ & + & + & - & + & - & & & & & & & & \\
\hline 29 & 2007 & $\begin{array}{l}\text { National Cancer } \\
\text { Institute }\end{array}$ & + & + & - & - & - & - & - & - & - & + & + & - & + \\
\hline
\end{tabular}

${ }^{\mathrm{a}}$ Stands for 'Not mentioned'.

${ }^{\mathrm{b}}$ Does not explicitly mention children in its recommendations, but does so briefly in appendices.

With regard to new collections it is stated that 'Consent should be written and specific procedures should be provided for vulnerable subjects and vulnerable populations, based on the general principle of acting in their best interest.'

Does not specify whether this has to be both parents.

'Tests of known predictive value for adult onset diseases should not be done for research purposes on individually identifiable sample from children'.

${ }^{f}$ Contains some information about biological samples, but not from children. Contains general information about children in research.

${ }^{9}$ Only mentions children with regard to genetic testing.

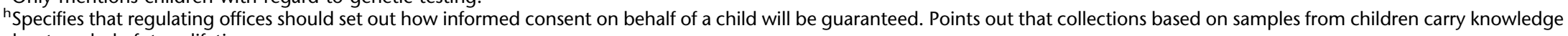
about a whole future lifetime.

"The opinion of a minor should be taken into consideration as an increasingly determining factor in proportion to age and degree of maturity".

'Data from children used for non-therapeutic research must be coded.

${ }^{k}$ Does not mention whether this has to be both parents.

'Does not mention children explicitly: 'Where authorization has been given on behalf of a person not able to consent, the representative, authority, person or body provided for by law should have the rights referred to in paragraph 1 above'.

'Where a person on whose behalf authorization has been given attains the capacity to give consent, that person should have the rights referred to in paragraph 1 above'.

${ }^{\mathrm{n}}$ Does not specify whether this has to be both parents. 
extent of such proxy consent. UNESCO (19) states that 'the legal representative should have regard to the best interest of the person concerned'.

Should a minor's decision also be taken into account, next to the proxy consent by the parent(s) or legal guardian? 11 out of the 18 documents discuss the issue of assent (permission) and dissent (refusal). All 11 agree that, when appropriate, the child should be consulted and their agreement should be obtained $(2,6,9,11,17,20,19,22$, 23,27 , and 28). Some documents state that a procedure should not be carried out if a child objects or seems to object to the procedures $(2,11,17,20,22,23,27$, and 28). In this respect, CIOMS (11) makes a distinction between the deliberate objection of an older child and 'the behavior of an infant, who is likely to cry or withdraw in response to any stimulus'. Therefore, older children, in whom an apparent objection can be more easily evaluated, should be preferred over younger children. CIOMS also states 'that a deliberate objection by a child to contribute to research should always be respected, even if the parents have given permission, unless the child needs treatment that is unavailable outside the context of research.' The Australian National Health and Medical Research Council (6) mentions the concept of the mature minor. If the child is a mature minor, his or her consent should be sought in addition to that of the parents or legal guardian. CIOMS (11) mentions that assent alone is insufficient to permit participation in research; additional consent from a legal guardian must be sought.

Should children be recontacted to give their autonomous consent for research on their samples? Eight documents think so $(1,9,23,24,6,11$ and 29). The criterion when this should happen varies however. Two guidelines mention 'when they are old enough to understand/comprehend or when they are capable of discernment' $(1,9,23$, and 24). CIOMS (11) mentions 'If such research subjects, including children, become capable of giving independent informed consent during the research, their consent to continued participation should be obtained'. They do not specify whether they mean a legal age or a level of maturity. Two documents $(6,29)$ specifically state that reconsent must occur when the child is legally capable of doing so.

\section{Principles of non-therapeutic research on minors}

A second topic is the reference to general principles of nontherapeutic research on children. These principles include first the fact that such research should not entail more than minimal risk, second that it can only be done to benefit persons of the same age or condition, third that they should have some direct benefit to the participant, and fourth that they can only be carried out if the same research cannot be done on adults.

The first general principle with regard to non-therapeutic research on children that is quoted in the context of stored tissue samples is that of minimal risk. Eight documents mention this risk $(2,11,17,20,21,22,23$ and 27). MRC (9) does not explicitly mention the principle, but states that 'Tests of known predictive value for adult onset diseases should not be done for research purposes on individually identifiable samples from children', thus quoting a specific interpretation of risk. CIOMS (11) gives a definition of what minimal risk might entail: 'the risk from research interventions that do not hold out the prospect of direct benefit for the individual subject should be no more likely and not greater than the risk attached to routine medical or psychological examination of such persons'. They make a distinction between the experiences of healthy children and those with a condition that would already require interventions as lumbar punctures or bone-marrow aspirations. Those would be ruled out for healthy children. Nationaler Ethikrat (22) mentions residual material from therapy or diagnosis: as research on such material does not require extra bodily interventions, the risk is considered minimal.

The next three principles are a reflection of the WMA's Declaration of Helsinki (1964), ${ }^{45}$ that states that 'these groups should not be included in research unless the research is necessary to promote the health of the population represented and this research cannot instead be carried out on legally competent persons'.

The second principle states that research should be beneficial to minors with the same age or same condition. This principle is quoted by five documents $(11,17,20,22,23)$. The WHO (20) states, however, that data should be coded to prevent identifiable links being made, and that 'such permissions would only normally be granted to the direct clinical benefit of the child'. Nationaler Ethikrat (22) quotes a controversy surrounding the concept of 'group benefits'. They state that 'some hold that, if research is of minimal risk and done on residual material from therapy or diagnosis, non-therapeutic research can be done on subjects incapable of giving consent for the benefit of fellow-sufferers. Others hold that consent is a personal matter and must be left to those concerned, and as it is impossible to determine whether risks are minimal, research on persons not able to consent should be prohibited'. The Nationaler Ethikrat does not, however, give a definite solution to the controversy.

A third principle that research on subjects who cannot consent should only be done if there is any direct benefit to participants, is quoted by four guidelines $(11,17,20,22)$. For example, the Nationaler Ethikrat (22) states that 'No one disputes that those incapable of giving consent may be involved in research from which they themselves are likely to benefit therapeutically'. None of the documents give examples as to how this can be interpreted in the context of stored tissue samples, as probably no such examples exist.

A fourth principle of research on children is that it should only be done if it cannot be done on adults. This is 
mentioned by six documents $(1,2,4,11,22,23)$. For example, the Irish Council of Bioethics states the condition that 'the research relates directly to a clinical condition from which the minor concerned suffers and/or is of such a nature that it can only be carried out on minors'. The other five documents have similar provisions.

\section{Ethics committee approval}

Seven guidelines mention the need for ethics committee approval for the inclusion of children in research $(2,11,14$, 20, 21, 29 and 27). The circumstances under which such approval is needed vary.

Four guidelines mention the need for ethics committee approval in general for research involving children $(2,20$, 21, and 27). CIOMS (11) mentions the need for such approval when there is a slight or minor increase above minimal risk. The Bioethics Advisory Committee, Singapore (14) mentions that the standard protocols and forms to be used in the taking of consent given on behalf of incompetent donors by their legal proxies should be reviewed and settled by the institution's ethics board or institutional review board, acting with the advice of the institution's legal advisors. The same ethics boards and legal advisors may also be consulted for a review of consent formalities in research projects for which it is anticipated that a significant proportion of the donors are or are likely to be legally incompetent'. NCI (19) mentions that the IRB should review reconsent issues when the child reaches the legal age to consent, at the time the board reviews the initial protocol.

\section{Difference between anonymous and identifiable}

Three documents make a distinction between the use of anonymous and linked biological samples from children $(9,20,29)$. MRC (9) states that 'tests of known predictive value should not be done for research purposes on individually identifiable samples from children', without further explanation. WHO (20) states that 'some research will require the linking of clinical and genetic data in order to proceed and that the main beneficiaries of this research may be future children rather than the child who provides the sample. In such cases data should be coded to prevent identifiable links being made with access to the key to the code being restricted and subject to separate permission on each occasion'. The NCI (29) mentions the need for reconsent when a child reaches the legal age to consent if identifiable samples are used.

\section{Discussion}

Of the 29 documents that mention stored tissue samples, 18 mention special provisions when these samples originate from children. These provisions include thoughts about consent, assent, reconsent, minimal risks, group or individual benefits, ethics committee revision and the difference between anonymous and identifiable stored samples. We have observed that these themes are not consistently mentioned by each document. Documents that discuss the same themes were mostly in agreement in their recommendations. The guidelines do not provide specific recommendations regarding ownership of tissues, return of results or recommendations when minors are concerned, probably because they do not consider these different from issues regarding tissue from adults.

\section{Consent}

Most policies agree that an informed consent must be obtained when biological samples and genetic material are collected for research. Moreover, 15 documents state that this should be written $(4,5,6,7,8,9,10,13,17,21,25,26$, 27 and 28). When minors that are incompetent, be it through lack of maturity or because they do not have the legal age to consent, are concerned, this is problematic. 17 guidelines mention that a legal guardian or parent is the most suitable person to consent. However, the nature of genetic material might suggest that, if possible, both parents should consent, as their genetic material is equally present in the child. This is suggested by Bauman. ${ }^{46}$ However, in a society in which many children do not live with both (biological) parents, this may be not feasible. ${ }^{47}$

With regard to assent, guidelines remain vague regarding at which age a child should be asked for his or her assent and whether the criterion is one of maturity or age. Most guidelines use general terminology such as 'his or her opinion should be taken into account depending on age and maturity' (28). Only one document mentions the age of 12 or 13 years old, in its general section on biomedical research involving minors (11). This uncertainty is reflected in the literature on assent: there is no consensus at which age a child should be allowed to assent for nontherapeutic research, and whether this age should be fixed, ${ }^{48}$ or is dependent on social context and personal experience. ${ }^{49}$ Moreover, Alderson has shown that already very small children are able to show objections to certain practices. It is fruitful to look at the United Nations Convention on the Rights of the Child, that asserts that children have a right to say what they think should happen when adults make decisions that affect them (Article 12) and have the right to get and share information (Article 13). As this is a legally binding document for most countries, it makes sense that in longitudinal genetic research, small children are also given appropriate information and their opinions are taken into account.

What should be the scope of parental consent in time and in content? Literature supports that it is reasonable to recontact minors when they are able to do so and give them the opportunity to withdraw their data, which is 
there only by proxy consent. ${ }^{50}$ However, none of the guidelines studied is explicit about when this should happen: when they are able to understand the impacts of research or when they reach a certain age? An overview of legal regulations regarding the position of minors in a health care setting in the EU member states has shown that age and circumstances under which minors are allowed to take health care decisions vary in different countries. ${ }^{51}$ In some countries, the age of medical majority is the same as the legal age of majority (Cyprus, Greece and Slovakia). Others distinguish between the medical and legal majority (Portugal, Slovenia, Lithuania and Spain). The Czech Republic and Estonia consider medical majority on a case-by-case basis, dependent on age and maturity.

Another aspect of the scope of consent is the question of content of the consent. Are parents allowed to consent to any future genetic research on their children's DNA? This is called broad consent. ${ }^{52}$ Or can they only give specific consent to research on specific genes and diseases? Most biobanks have as an aim the accommodation of future research, the nature of which is undetermined at the moment of storage. Hansson ${ }^{53}$ has argued that broad consent at the time of storage is sufficient to keep the data available for research for a long period of time. In the case of children, however, it is not the donor herself who has consented and it may seem fair to restrict proxy consent only to specific research protocols or research on certain genes or diseases.

\section{Principles of research on children}

Most would consider biobank research in general as minimal risk. ${ }^{9}$ There is probably very little harm involved in the taking of a sample of blood of an adult to be included in a biobank. The harm is mostly situated in the area of possible stigmatization of certain groups through genetic research and the risk of loss of privacy. ${ }^{9}$ However, for children, procedures such as having blood taken and visiting a hospital or research center may well be frightening. The amount of anxiety that such procedures cause is probably dependent on the personality and experience of each individual child, and the question whether a child should be enrolled or not in non-therapeutic research is hence one that has to be made on a case-by-case basis.

The issue of privacy, which is often quoted with regard to biobanks in general, is a difficult one when children are concerned. It can be argued that the privacy of an infant is not that important and that his or her medical information is more or less public property. Most parents discuss a variety of health related issues about their baby with different people; they would probably refrain from doing this if an older child was concerned. Indeed, the need for privacy grows as the child grows older, and what a child considers private is in many cases different from what an adult would be sensitive about. ${ }^{54}$ Some consider genetic data as a 'future diary', a term framed by Annas: ${ }^{55}$ we would not find it acceptable to publish a diary of a ten year old. Moreover, the DNA of the child is the same as the DNA of the adult it is to become. The combination of the static characteristics of genetic information together with the evolution of the child towards maturity makes the question of privacy and minimal risk in biobanks that store pediatric samples a difficult one to answer. The topic of privacy and children was not explored further by any of the guidelines under consideration.

A next requirement is that of who should benefit from non-therapeutic research on tissue from children. Although some people acknowledge that there could be direct benefits to the individual from being enrolled in biobank research, such as benefits from regular health checkups, ${ }^{56}$ this is not the primary aim of the research. Therefore, it is difficult to envisage what direct benefit would mean in this respect. On the criterion of group benefits, Holm ${ }^{50}$ has argued that these are too restrictive and not well founded as criterion, and that parents should be allowed to consent to participation of their children regardless of these benefits. However, in the context of proxy consent and broad versus specific consent, it may seem reasonable that proxy consent is not given for research on the entire genome of a child, but restricted to research on specific genes or conditions, which would satisfy the requirement of group benefits as well.

\section{Ethics committee review and anonymization}

No consistent overview of the issues that an ethics committee should take into account when considering research on children could be found. Moreover, it is remarkable that only a subset of guidelines (7 out of 29) mentions this specifically with regard to research on minors, as it could be deemed good practice.

The Declaration of Helsinki ${ }^{45}$ considers research on identifiable human materials as human subject research, but can this be generalized to the use of anonymized samples? If research on anonymous samples is not considered human subject research, maybe the provisions that are put on research on tissue samples from children do not apply. In the context of risk, some authors in ethical literature have argued that the risk of privacy breaches is removed when anonymous samples are used. ${ }^{57,58}$ However, others such as Lysaught, ${ }^{59}$ point out to the possibility that genetic research may lead to group stigma, and hence indirectly may affect the individual. Moreover, subjects may feel strongly about the type of research that is done on their tissue, regardless of the level of identifiability, as mentioned by Trouet. ${ }^{60}$

The storage and use of biological samples from children for research poses some specific questions that are not covered by ethical reflections on the use of samples from human beings in general, such as who should give consent, whether the opinions of the minors matter, to which risks children can be exposed and who should benefit from such 
research. The majority of the 29 guidelines does reflect this distinction and mentions children in a separate section. However, a systematic reflection is missing and should be subject to further study. Such study could also shed some light on existing general discussions with regard to the ethics of biobanks, most notably the issue of informed consent.

\section{Acknowledgements}

This work was supported by GeneBanC, an EU-FP6 supported STREP contract number 036751 and FWO Flanders, project number G029107.

\section{References}

1 Ollier W, Sprosen T, Peakman T: UK Biobank: from concept to reality. Pharmacogenomics 2005; 6: 639-646.

2 Klotz J, Bryant P, Wilcox HB, Dillon M, Wolf B, Fagliano J: Population-based retrieval of newborn dried blood spots for researching paediatric cancer susceptibility genes. Pediatr Perinat Epidemiol 2006; 20: 449-452.

3 Rasmussen SA, Lammer EJ, Shaw GM et al: Integration of DNA sample collection into a multi-site birth defects case-control study. Teratology 2002; 66: 177-184.

4 Pembrey M: The Avon Longitudinal Study of Parents and Children (ALSPAC): a resource for genetic epidemiology. Eur J Endocrinol 2004; 151 (Suppl 3): 125-129.

5 Chadwick R, Berg K: Solidarity and equity: new ethical frameworks for genetic databases. Nat Rev Genet 2001; 2: 318-321.

6 Charo AR: Body of research - ownership and use of human tissue. N Eng J Med 2006; 355: 1517-1519.

7 Clayton EW: Informed consent and biobanks. J Law Med Ethics 2005; 33: 15-21.

8 Deschênes M, Glass KC, Cardinal G, Knoppers BM: Human genetic research, DNA banking and consent: a question of 'form'? Clin Genet 2001; 59: 221-239.

9 Eriksson S, Helgesson G: Potential harms, anonymization, and the right to withdraw consent to biobank research. Eur J Hum Genet 2005; 13: 1071-1076.

10 Godard B, Aymé S, Schmidtke J, Cassiman J-J: Data storage and DNA banking for biomedical research: informed consent, confidentiality, quality issues, ownership, return of benefits. A professional perspective. Eur J Hum Genet 2003; 11 (Suppl 2): $88-122$.

11 Knoppers BM: Biobanking: international norms 10. J Law Med Ethics 2005; 33: 7-14.

12 Petersen A: 'Biobanks' 'engagements': engendering trust or engineering consent? Genomics Soc Policy 2007; 3: 31-43.

13 Roche PA, Annas GJ: DNA testing, banking, and genetic privacy. N Eng J Med 2006; 355: 545-546.

14 Williams G, Schroeder D: Human genetic banking: altruism, benefit and consent. New Genet Soc 2004; 23: 89-103.

15 Borry P, Nys H, Goffin T, Dierickx K: Genetic testing and counselling. European Guidance. European Ethical-Legal Papers no. 3, 2007.

16 Fuchs M: National Ethics Councils: Their Backgrounds, Functions and Modes of Operation Compared. Berlin: German National Ethics Council, 2005.

17 Gezondheidsraad: Commissie Lichaamsmateriaalvoor bijzondere doeleinden: Naar goed gebruik. Lichaamsmateriaal in de gezondheidszorg 1994.

18 Nuffield Council on Bioethics: Human Tissue, Ethical and Legal Issues 1995.

19 HUGO Ethics Committee: HUGO Ethics Committee: Statement on DNA Sampling: Control and Access 1998.
20 American Medical Association: E-2.07 Clinical Investigation 1998.

21 National Bioethics Commission: Recommendation on Banks of Biological Material of Human Origin (Biobanks) in Biomedical Research 2006.

22 National Health and Medical Research Council: Guidelines for Genetic Registers and Associated Genetic Material 2000.

23 Visindasidanefnd: Biological Samples 2000.

24 ESHG: Data storage and DNA banking for biomedical research: technical, social and ethical issues. Eur J Hum Genet 2001; 11 (S2): S8-S10.

25 Medical Research Council: Human Tissue and Biological Samples for Use in Research - Operational and Ethical Guidelines 2001.

26 The Sub-Committee on Medical Research Ethics (TUKIJA) of the National Advisory Board on Health Care Ethics: DNA Samples in Epidemiological Research 2002.

27 Council for International Organizations of Medical Science (CIOMS): International Ethical Guidelines for Biomedical Research Involving Human Subjects 2002.

28 HUGO Ethics Committee: HUGO Ethics Committee: Statement on Human Genomic Databases 2002.

29 Bioethics Advisory Committee of the Israel Academy of Sciences and Humanities: Population-Based Large-Scale Collections of DNA Samples and Databases of Genetic Information 2002.

30 Bioethics Advisory Committee Singapore: Human Tissue Research 2002.

31 Human Genetics Commission: Inside Information 2002.

32 American Medical Association: E-2.079. Safeguards in the Use of DNA Databanks in Genomic Research 2002.

33 Commission de l'éthique de la science et de la technologie: Les enjeux éthiques des banques d'information génétique: pour un encadrement démocratique et responsible 2003.

34 Comité consultatif national d'éthique pour les sciences de la vie et de la santé: Avis $n 77$ Problèmes éthiques posés par les collections de materiel biologiqueet les données d'information associées: 'biobanques' 'biotheques' 2003.

35 UNESCO: International Declaration on Human Genetic Data 2003.

36 World Health Organization: Genetic Databases. Assessing the Benefits and the Impacts on Human \& Patient Rights 2003.

37 Deutsche Gesellschaft für Humangenetik: DNA-banking and personenbezogene Daten in der biomedizinischen Forschung: Technische, soziale und ethische Frage 2004.

38 Nationaler Ethikrat: Biobanks for research 2004.

39 Irish Council for Bioethics: Human Biological Material: Recommendations for Collection, Use and Storage in Research 2005.

40 Council of Europe: Recommendation Rec(2006)4 of the Committee of Ministers to Member States on Research on Biological Materials of Human Origin 2006.

41 Swiss Academy of Medical Sciences: Biobanks: Obtainment, Preservation and Utilization of human Biological Material. MedicalEthical Guidelines and Recommendations 2006.

42 Austrian Bioethics Commission: Biobanken für die medizinische Forschung 2007.

43 NuGO Working Group: European Nutrigenomics Organisation (NUGO) Bioethics Guidelines on Human Studies 2007.

44 National Cancer Institute: Best Practices of Biospecimen Resources 2007.

45 World Medical Association (WMA): Declaration of Helsinki. Ethical Principles for Medical Research Involving Human Subjects 1964.

46 Baumann TK: Proxy consent and a national DNA databank: an unethical and discriminatory combination. Iowa Law Rev 2001; 86: $667-701$.

47 Ross LF: Ethical and policy issues in pediatric genetics. Am J Med Genet C Semin Med Genet 2008; 148C: 1-7.

48 Wendler D, Shah S: Should children decide whether they are enrolled in nonbeneficial research? Am J Bioeth 2003; 3: 1-7.

49 Ashcroft R, Goodenough T, Williamson E, Kent J: Children's consent to research participation: social context and personal experience in validate fixed cutoff rules. Am J Bioeth 2003; 3: 16-18. 
50 Holm S: Informed consent and the bio-banking of material from children. Genomics Soc Policy 2005; 1: 16-26.

51 Stultiëns L, Goffin T, Borry P, Dierickx K, Nys H: Minors and informed consent: a comparative approach. Eur J Health Law 2007; 14: 21-46.

52 Artizzu F: The informed consent aftermath of the genetic revolution. an Italian example of implementation. Med Health Care Philos 2008; 11: 181-190.

53 Hansson MG, Dillner J, Bartram CR, Carlson JA, Helgesson G: Should donors be allowed to give broad consent to future biobank research? Lancet Oncol 2006; 7: 266-269.

54 Williamson E, Goodenough T, Kent J, Ashcroft R: Children's participation in genetic epidemiology; in Tutton R, Corrigan O (eds): Genetic Databases: Socio-Ethical Issues in the Collection and Use of DNA. London and New York, Routledge, 2004, pp 139-160.

55 Annas GJ: Privacy rules for DNA databanks. Protecting coded 'future diaries'. J Am Med Assoc 1993; 270: 2346-2350.
56 Kaufman D, Geller G, LeRoy L, Murphy J, Scott J, Hudson K: Ethical implications of including children in a large biobank for genetic-epidemiologic research: a qualitative study of public opinion. Am J Med Genet C Semin Med Genet 2008; 148C: 31-39.

57 Therrell BL, Hannon WH, Pass KA et al: Guidelines for the retention, storage, and use of residual dried blood spot samples after newborn screening analysis: statement of the Council of Regional Networks for Genetic Services. Biochem Mol Med 1996; 57: 116-124.

58 Laberge C, Kharaboyan L, Avard D: Newborn screening, banking, and consent. GenEdit 2004; 2: 1-15.

59 Lysaught M, Milhollin L, Peirce R et al: A pilot test of DNA-based analysis using anonymized newborn screening cards in Iowa; in Stored Tissue Samples: Ethical Legal, and Public Policy Implications (eds): Iowa City: University of Iowa Press, 1998, pp $3-31$.

60 Trouet C: Van Lichaam Naar Lichaamsmateriaal. Recht En Het Nader Gebruik Van Cellen En Weefsels. Antwerpen: Intersentia, 2003. 